Al Maal : Journal of Islamic Economics and Banking

http://jurnal.umt.ac.id/index.php/jieb

E-ISSN : $2580-3816$

Vol : No 1 Vol 2 Bulan Januari Tahun 2020

Hlm : $164-175$

DOI $\quad$ : $10.31000 /$ almaal.v1i2.1878

\title{
Analisis Efektivitas Penyaluran Zakat pada Badan Amil Zakat Nasional
}

\author{
Efri Syamsul Bahri ${ }^{1 *}$, Sabik Khumaini ${ }^{2}$ \\ ${ }^{1}$ Prodi Akuntansi Syariah, Sekolah Tinggi Ekonomi Islam SEBI, Depok, Indonesia \\ ${ }^{2}$ Prodi Perbankan Syariah, Universitas Muhammadiyah Tangerang, Tangerang, Indonesia \\ *efri.sb@sebi.ac.id
}

\begin{abstract}
The National Zakat Board (BAZNAS) The Republic of Indonesia is a non-structural government institution that manages zakat nationally in Indone. The problem in this research is how the development of the collection and distribution of Zakat, Alms, and Other Religious Social Funds (ZIS and DSKL) and how effective is the distribution of BAZNAS zakat? The objectives of this study include: to measure the effectiveness of the distribution of BAZNAS ZIS and DSKL. This research uses qualitative and quantitative methods. The qualitative method uses a descriptive approach. While the quantitative method uses the Zakat Core Principle (ZCP) measurement model. The object used in this study is the BAZNAS financial statements for the period 2001 to 2018. The results of this study indicate that the total collection of ZIS and DSKL is 18 years, Rp932.648.351.752,19. While the amount of ZIS and DSKL distribution for 18 years, is Rp836.512.139.145,00. Based on the ZCP the effectiveness of distribution for 18 years of operation is $90 \%$ (ninety percent). This shows that the effectiveness of the distribution of ZIS and DSKL BAZNAS for 18 years is in the Highly Effective category where the Allocation to Collection Ratio (ACR) reaches $\geq 90$ percent.
\end{abstract}

Keywords: Effectiveness; Disbursement; Baznas; Zakat Core Principle; Zakat.

\section{ABSTRAK}

Badan Amil Zakat Nasional (BAZNAS) Republik Indonesia merupakan lembaga pemerintah nonstruktural yang melakukan pengelolaan zakat secara nasional di Indonesia. Permasalahan dalam penelitian ini adalah bagaimana efektivitas penyaluran zakat BAZNAS? Tujuan penelitian ini antara lain: untuk mengukur efektivtas penyaluran ZIS dan DSKL BAZNAS. Penelitian ini menggunakan metode kualitatif dan kuantitaif. Metode kualitatif menggunakan pendekatan deskriptif. Sedangkan metode kuantitatif menggunakan model pengukuran rasio Zakat Core Prinsiple (ZCP). Objek yang digunakan dalam penelitian ini adalah laporan keuangan BAZNAS selama rentang periode 2001 sampai dengan 2018. Hasil penelitian ini menunjukkan bahwa jumlah pengumpulan ZIS dan DSKL 18 tahun, Rp932.648.351.752,19. Sedangkan jumlah penyaluran ZIS dan DSKL selama 18 tahun, sebesar Rp836.512.139.145,00. Berdasarkan ZCP tingkat efektivitas penyaluran selama 18 tahun beroperasi sebesar $90 \%$ (sembilan puluh persen). Hal ini menunjukkan bahwa tingkat efektivitas penyaluran ZIS dan DSKL BAZNAS selama 18 tahun berada pada kategori Sangat Efektif dimana Alocation to Collection Ratio (ACR) mencapai $\geq 90$ persen.

Kata kunci : Efektivitas; Penyaluran;BAZNAS; Zakat Core Prinsiple; Zakat. 


\section{Pendahuluan}

Undang-Undang Nomor 23 Tahun 2011 Tentang Pengelolaan Zakat mengukuhkan peran BAZNAS sebagai lembaga yang berwenang mengelola zakat secara nasional. Dalam melaksanakan tugas, BAZNAS menyelenggarakan fungsi 4 (empat) fungsi, yaitu: a. perencanaan pengumpulan, pendistribusian, dan pendayagunaan zakat; b. pelaksanaan pengumpulan, pendistribusian, dan pendayagunaan zakat; c. pengendalian pengumpulan, pendistribusian, dan pendayagunaan zakat; dan d. pelaporan dan pertanggungjawaban pelaksanaan pengelolaan zakat.

Keempat fungsi tersebut merupakan rangkaian aktivitas yang tidak bisa dipisahkan. Perencanaan program menjadi titik awal keberhasilan program. Bentuk dokumen perencanaan adalah dokumen Rencana Strategis sebagai acuan program 5 (lima) tahunan serta dokumen Rencana Kegiatan dan Anggaran Tahunan (RKAT) sebagai acuan dalam pelaksanaan program setiap tahun.

Selanjutnya pelaksanaan dan pengendalian program menjadi kunci dalam keberhasilan program. Proses pelaksanaan pengendalian dapat dilakukan melalui kegiatan monitoring, evaluasi dan audit. Begitu juga pelaporan program tidak bisa dilepaskan, karena pengakuan terhadap penyaluran adalah ketika dana zakat sudah dilaporan dan dipastikan diterima oleh mustahik yang berhak. Hal ini mengacu pada Pernyataan Standar Akuntansi Keuangan No.109 yang menyebutkan bahwa Zakat yang disalurkan kepada mustahiq diakui sebagai pengurang dana zakat sebesar: (a) jumlah yang diserahkan, jika dalam bentuk kas; (b) jumlah tercatat, jika dalam bentuk aset nonkas.

Dalam rangka mengoptimalkan penyaluran zakat baik bidang pendistribusian maupun pendayagunaan, BAZNAS menyusun Rencana Strategis (Renstra) BAZNAS 2016-2020. Berdasarkan Renstra, terdapat 4 (empat) Indikator Kinerja Kunci (IKK) Aspek Penyaluran yang secara terinci dapat dilihat pada Tabel di bawah ini.

Tabel 1 Indikator Kinerja Kunci Aspek Penyaluran

\begin{tabular}{|c|c|c|c|c|c|c|c|}
\hline \multirow[t]{2}{*}{ No } & \multirow[t]{2}{*}{ Indikator Kinerja Kunci } & \multirow[t]{2}{*}{ Satuan } & \multicolumn{5}{|c|}{ Target } \\
\hline & & & 2016 & 2017 & 2018 & 2019 & 2020 \\
\hline 1 & $\begin{array}{r}\text { Rasio penyaluran terhadap } \\
\text { pengumpulan diatas } 70 \%\end{array}$ & $\begin{array}{r}\text { Triliun } \\
\text { IDR }\end{array}$ & 3,50 & 4,55 & 6,14 & 8,59 & 12,04 \\
\hline 2 & $\begin{array}{r}\text { Fakir Miskin Yang Dientaskan dari } \\
\text { Garis Kemiskinan sebesar } 1 \% \text { setiap } \\
\text { tahun dari jumlah orang miskin } \\
\text { berdasarkan data BPS }\end{array}$ & $\begin{array}{l}\text { Ribu } \\
\text { orang }\end{array}$ & 280 & 280 & 280 & 280 & 280 \\
\hline 3 & $\begin{array}{r}\text { Terlaksananya program bina desa } \\
\text { zakat produktif }\end{array}$ & Desa & 40 & 81 & 121 & 141 & 161 \\
\hline 4 & Database mustahik BAZNAS & Waktu & Okt & Juli & Juli & Juli & Juli \\
\hline
\end{tabular}

Sumber: (BAZNAS, 2016) 
Berdasarkan tabel di atas, IKK Aspek Penyaluran yang pertama adalah rasio penyaluran terhadap pengumpulan di atas $70 \%$ (tidak termasuk alokasi dana amil). Selama lima tahun, dari 2016 s/d 2020 ditargetkan jumlah penyaluran sebesar Rp31,82 triliun dengan rincian 3,5 tiliun (2016), 4,55 triliun (2017), 6,14 triliun (2018), 8,59 triliun (2019), dan 12,04 triliun (2020). IKK Aspek Penyaluran yang kedua, yakni: Fakir Miskin Yang Dientaskan dari Garis Kemiskinan sebesar 1\% setiap tahun dari jumlah orang miskin berdasarkan data BPS. Ditargetkan setiap tahun BAZNAS berkontribusi untuk mengantaskan 280.000 orang.

IKK Aspek Penyaluran yang ketiga, yakni: Terlaksananya program bina desa zakat produktif dengan target sebagai berikut: tahun 201640 desa, tahun 2017 menjadi 81 desa, tahun 2018 menjadi 121 desa, tahun 2019 menjadi 141 desa dan tahun 2020 menjadi 161 desa. IKK Aspek Penyaluran yang keempat adalah Database mustahik BAZNAS. Diharapkan database mustahik sudah tersedia bulan Oktober 2016, Juli 2017, Juli 2018, Juli 2018, Juli 2019 dan Juli 2020.

Dari uraian latar belakang diatas peneliti tertarik untuk meneliti tentang efektivitas penyaluran zakat yang dalam hal ini termasuk di dalamnya infak/sedekah serta dana sosial keagamaan lainnya (DSKL) yang dikelola oleh Badan Amil Zakat Nasional yang didirkan melalui Keputusan Presiden Republik Indonesia No.8 Tahun 2001. Oleh karena itu peneliti mengambil judul "Analisis Efektivitas Penyaluran Zakat pada Badan Amil Zakat Nasional". Pengukuran efektivitas (Bahri S. d., 2018, hal. 221) penyaluran zakat ini sejalan dengan amanat Undang-Undang No.23 Tahun 2011 Tentang Pengelolaan Zakat yang menyebutkan bahwa tujuan pengelolaan zakat adalah untuk meningkatkan efektivitas dan efisiensi pelayanan dalam pengelolaan zakat, dan meningkatkan manfaat zakat untuk mewujudkan kesejahteraan masyarakat dan penanggulangan kemiskinan.

\section{KAJIAN LITERATUR Definisi Zakat}

Secara bahasa, kata zakat mempunyai beberapa arti, yaitu al-barakatu (keberkahan), an-namaa (pertumbuhan dan perkembangan), ath-thaharatu (kesucian), dan ash-shalahu (keberesan) (Dhaif, 2011). Sesuatu itu zaka, berarti tumbuh dan berkembang, dan orang itu zaka, berarti orang itu baik (Qardhawi, 2016). Zakat menurut etimologi berarti, berkah, bersih, berkembang dan baik.

Zakat menurut istilah fikih adalah sejumlah harta tertentu yang diwajibkan Allah diserahkan kepada orang yang berhak menerimanya, di samping berarti mengeluarkan jumlah tertentu itu sendiri (Qardhawi, 193:34); (Deni Lubis, 2018, hal. 1), diberikan kepada golongan yang berhak menerimanya menurut ketentuan yang telah ditetapkan oleh Islam yang menurut Ibnu Taimiyah hati dan harta orang yang membayar zakat tersebut menjadi suci dan bersih serta berkembang secara maknawi (Chaniago, 2015, hal. 48).

Umar bin Abdul Aziz mengikuti sunnah Nabi dalam hal penarikan zakat, ia menunjuk para petugas yang amanah dan dapat dipercaya, lalu menyuruh mereka untuk menarik harta yang diwajibkan untuk dizakatkan tanpa berlebih-lebihan atau bahkanmendzhalimi. Kemudian Umar memerintahkan para petugas itu untuk mencatatkan resi tanda pelunasan untuk para pembayarnya hingga mereka tidak harus membayar lagi kecuali telah berganti tahun. Lalu Umar juga memastikan setiap kelompok 
yang berhak menerima zakat harus menerima zakat tersebut di daerahnya masing-masing kecuali mereka sudah berkecukupan. (Ali Muhammad Ash Shalabi: 2014:440); (Harahap, 2016)

Zakat merupakan kewajiban yang diperintahkan langsung oleh Allah SWT dalam Al-Quran (Reni Oktaviani, 2018, hal. 101), ibadah yang memiliki posisi yang sangat strategis baik dari aspek keagamaan, sosial, ekonomi, dan kesejahteraan masyarakat (BAZNAS, 2016, hal. 5) dan menjadi salah satu instrumen yang paling efektif membantu permasalahan kemiskinan (Sabik Khumaini, 2018, hal. 155). Dalam upaya berkontribusi terhadap berbagai aspek di dalam pembangunan, maka program-program pendistribusian dan pendayagunaan juga mencakuap berbagai bidang di dalam pembangunan antara lain: ekonomi, pendidikan, kesehatan, kemanusiaan serta dakwah dan advokasi.

Di dalam bidang ekonomi, zakat memiliki banyak peran dan fungsi, antara lain: sebagai sumber dana pengentasan kemiskinan (Atabik, 2016) dan sumber modal kerja (Sartika, 2008); (Reni Oktaviani, 2018, hal. 118). Zakat juga berperan di dalam membuka lapangan pekerjaan (Rozalindah, 2014:248). Dengan pengelolaan usaha yang baik oleh mustahik, diharapkan mampu menambah dan mencukup kebutuhan sehari-hari mereka (Rozalindah, 2014: 248) (Atabik, 2016). Bahkan secara makro, dana zakat mempunyai fungsi alokatif dan stabilisator perekonomian (El-Din, 1986); (Beik 2009) dalam (Firmansyah, 2013, hal. 180), menjadi solusi untuk masalah yang dihadapi oleh pengusaha mikro (Efri Syamsul Bahri, 2019, hal. 259).

Begitu juga peran dan fungsi zakat di bidang-bidang lainnya. Bahkan, implementasi kelima bidang tersebut juga dapat dilakukan secara terintegrasi dengan pelaksanaan berbasis komunitas. Program zakat berbasis komunitas mencakup 5 (lima) ukuran dimensi, yaitu: dimensi ekonomi, kesehatan, pendidikan, sosial dan kemanusiaan, serta dakwah (Bahri E. S., 2018).

\section{Penyaluran Zakat}

Menurut Kamus Besar Bahasa Indonesia (KBBI) penyaluran berarti proses, cara, perbuatan menyalurkan. (KBBI). Dengan demikian, penyaluran zakat merupakan proses, cara, perbuatan menyalurkan zakat kepada yang berhak. Abdus Sami (2010) mengatakan bahwa objek atau sasaran zakat adalah sebagaimana yang telah tertera dalam Al-Qur'an surat At-Taubah ayat 60, yaitu terdiri dari: Fakir, Miskin, Amil, Muallaf, Riqob, Ghorimin, Ibnu sabil dan Fii sabilillah. "Sesungguhnya zakat-zakat itu, hanyalah untuk orang-orang fakir, orang-orang miskin, amil zakat, para mualaf yang dibujuk hatinya, untuk (memerdekakan) budak, orang-orang yang berutang, untuk jalan Allah dan untuk mereka yang sedang dalam perjalanan, sebagai suatu ketetapan yang diwajibkan Allah, dan Allah Maha Mengetahui lagi Maha Bijaksana" (QS At-Taubah: 60).

Berdasarkan Peraturan Badan Amil Zakat Nasional (BAZNAS) No.3 Tahun 2018, pengertian masing-masing asnaf sebagai penerima manfaat zakat adalah sebagai perikut. Fakir merupakan orang yang sama sekali tidak mempunyai sumber mata pencaharian untuk memenuhi kebutuhan dasar. Miskin merupakan orang yang mempunyai sumber mata pencaharian tetapi tidak mempunyai kemampuan memenuhi kebutuhan dasar yang layak bagi kehidupan dirinya dan/atau keluarga yang menjadi tanggungannya. Amil merupakan seseorang atau sekelompok orang yang diangkat dan/atau diberi kewenangan oleh pemerintah, pemerintah daerah, badan, lembaga yang diberikan izin oleh pemerintah 
dan/atau pemerintah daerah, dan/atau seseorang yang mendapat mandat dari pimpinan Pengelola Zakat untuk mengelola Zakat.

Mualaf merupakan orang yang sedang dikuatkan keyakinannya karena baru masuk Islam. Riqab merupakan orang Islam yang menjadi: a. korban perdagangan manusia; $b$. pihak yang ditawan oleh musuh Islam; atau c. orang yang terjajah dan teraniaya. Gharimin merupakan orang yang berutang untuk: a. kemaslahatan diri dengan tidak berlebihan seperti untuk nafkah, mengobati orang sakit, membangun rumah, dan lain sebagainya; $b$. kemaslahatan umum seperti mendamaikan dua orang muslim atau lebih yang sedang berselisih sehingga perlu adanya biaya yang harus dikeluarkan untuk menyelesaikannya; atau c. kemaslahatan umum lainnya seperti membangun sarana ibadah dan tidak sanggup membayar pada saat jatuh tempo pembayaran.

Sabilillah merupakan salah satu dari golongan dibawah ini, yaitu: a. orang atau kelompok/lembaga yang sedang berjuang menegakan kalimat Allah; b. orang yang secara ikhlas melaksanakan tuntunan agama baik tuntunan wajib, sunah, dan berbagai kebajikan lainnya untuk mendekatkan diri kepada Allah SWT; atau c. orang yang secara ikhlas dan sungguh-sungguh dalam menuntut ilmu yang bermanfaat bagi umat. Ibnu Sabil merupakan para musafir yang kehabisan biaya atau bekal dalam melakukan perjalanan untuk sesuatu yang baik.

Penyaluran zakat juga dapat dikategorikan menjadi dua bidang, yaitu: pendistribusian dan pendayagunaan. Sesuai dengan Peraturan BAZNAS No.3 Tahun 2018 Tentang Pendistribusian dan Pendayagunaan, yang dimaksud pendistribusian adalah penyaluran zakat kepada mustahik dalam bentuk konsumtif. Sedangkan pendayagunaan adalah pemanfaatan zakat secara optimal tanpa mengurangi nilai dan kegunaannya dalam bentuk usaha produktif, sehingga berdayaguna untuk mencapai kemaslahatan umum.

Zakat untuk pendistribusian sebelumnya banyak disebut dengan istilah zakat konsumtif. Sedangkan pendayagunaan disebut dengan istilah zakat produktif. Zakat konsumtif diberikan untuk memenuhi kebutuhan sehari-hari mustahik (Reni Oktaviani, 2018, hal. 104), mencukupi kebutuhan hidup sehari-hari masyarakat miskin/mustahik (Setiawan, 2017, hal. 249).

sedangkan zakat produktif bertujuan untuk selain mejadikan mustahik menjadi mandiri dan diharapkan kedepannya mampu menjadi muzaki. Zakat produktif diartikan sebagai cara (Yasir, 2014) dan mekanisme (Pratama, 2015) dalam mengatasi masalah kemiskinan. Zakat produktif (Sartika, 2008) dapat digunakan untuk modal kerja (Efri Syamsul Bahri, 2019), diberikan kepada mustahiq di antara orang miskin dan yang membutuhkan pada umumnya, yang memiliki mikro-kecil.

Antara zakat konsumtif dan zakat produktif (Khalifah Muhamad Ali, 2016), memiliki persamaam, perbedaaan, kelemahan dan kelebihan. Pertama, persamaan zakat konsumtif dan zakat produktif adalah sama-sama mampu meningkatkan kesejahteraan sekaligus menurunkan kemiskinan mustahik. Perbedaan antara zakat konsumtif dan zakat produktif adalah zakat produktif dianggap lebih mampu mengurangi kemiskinan dibanding zakat konsumtif. Faktor-faktor yang menjadi penyebab bahwa zakat produktif memiliki kelebihan dari zakat konsumtif adalah dimana zakat produktif diiringi dengan adanya pendampingan usaha dan pembinaan keagamaan. 
Kedua, pada zakat produktif faktor-faktor yang berpengaruh dalam penanggulangan kemiskinan adalah pendapatan rumah tangga mustahik dan pekerjaan kepala rumah tangga. Sedangkan pada zakat konsumtif faktor-faktor yang berpengaruh adalah pendidikan kepala rumah tangga dan pendapatan rumah tangga mustahik. Dengan demikian, persamaan zakat konsumtif dan zakat produktif adalah pada faktor pendapatan yang sama-sama berpengaruh dalam penanggulangan kemiskinan. Sedangkan persamaannya adalah pada dasarnya sama-sama mampu untuk meningkatkan kesejahteraan sekaligus menurunkan kemiskinan mustahik. Perbedaannya, zakat produktif lebih mampu mengurangi kemiskinan dibanding zakat konsumtif.

Keberadaan zakat produktif mampu meningkatkan pendapatan mustahik (Widiastuti, 2015, hal. 90), berpengaruh signifikan terhadap peningkatan pendapatan sebesar 25,2\%, pendidikan 22,9\% dan sehat 8,9\% (Damanhur, 2017, hal. 77), mampu meningkatkan keadaan ekonomi pelaku Usaha Kecil Menengah (Setiawan, 2017, hal. 247) dan efektif untuk mengubah kehidupan mustahiq (Imron Mawardi, 2018, hal. 133).

\section{Efektivitas Penyaluran Zakat}

Efektivitas (Rifa'i, 2013, hal. 132) dapat diartikan sebagai sebuah keberhasilan suatu aktivitas atau kegiatan dalam mencapai tujuan (sasaran) yang telah ditentukan sebelumnya. Efektivitas penyaluran zakat diukur dengan menggunakan Zakat Core Principles (ZCP). Penilaian efektivitas penyaluran zakat dengan menggunakan ZCP bertujuan untuk mengetahui bagaimana penyaluran dana zakat yang dikelola Baznas telah memenuhi standar kriteria efektif sesuai dengan acuannya sehingga pengelolaannya dapat dipertanggungjawabkan.

Berdasarkan ZCP, maka rasio yang digunakan adalah Allocation to Collection Ratio (ACR). Rasio ini digunakan untuk mengukur kemampuan sebuah lembaga zakat dalam menyalurkan dana zakatnya dengan cara membagi total dana penyaluran dengan total dana penghimpunan. Penilaian ACR terdiri dari beberapa kategori, dengan rincian sebagai berikut: 1. Highly Effective (jika ACR $\geq 90$ persen) 2. Effective (jika ACR mencapai 70- 89 persen) 3. Fairly Effective (jika ACR mencapai 50- 69 persen) 4. Below Expectation (jika ACR mencapai 20- 49 persen) 5. Ineffective (jika ACR < 20 persen) (BAZNAS P. , 2018, hal. 70-71).

\section{Metode Penelitian}

Penelitian ini menggunakan metode penggabungan antara metode kualitatif dan kuantitaif. Penelitian kualitatif adalah penelitian yang bermaksud untuk memahami fenomena tentang apa yang dialami oleh subjek penelitian misalnya perilaku, persepsi, motivasi, tindakan, dan lain-lain secara holistik. Pendekatan yang dilakukan adalah dengan cara deskripsi dalam bentuk kata-kata dan bahasa, pada suatu konteks khusus yang alamiah dan dengan memanfaatkan berbagai metode alamiah (Kuntjojo, 2009, hal. 14-15). Sedangkan penelitian kuantitatif adalah suatu proses menemukan pengetahuan yang menggunakan data berupa angka sebagai alat menganalisis keterangan mengenai apa yang ingin diketahui.

Metode kualitatif pada penelitian ini menggunakan pendekatan deskriptif dan studi literatur. Sedangkan metode kuantitatif dengan menggunakan rasio pengukuran Zakat Core Principle. Objek yang digunakan dalam penelitian ini adalah laporan penyaluran BAZNAS selama rentang periode 2001 sampai dengan 2018. Penelitian ini 
dibatasi di Badan Amil Zakat Nasional untuk periode pelaporan penyaluran tahun 2001 sampai dengan 2018.

\section{Hasil dan Pembahasan \\ Badan Amil Zakat Nasional}

Badan Amil Zakat Nasional (BAZNAS) merupakan badan resmi dan satu-satunya yang dibentuk oleh pemerintah berdasarkan Keputusan Presiden RI No. 8 Tahun 2001 yang memiliki tugas dan fungsi menghimpun dan menyalurkan zakat, infaq, dan sedekah (ZIS) pada tingkat nasional. Lahirnya Undang-Undang Nomor 23 Tahun 2011 tentang Pengelolaan Zakat mengukuhkan peran BAZNAS sebagai lembaga yang berwenang melakukan pengelolaan zakat secara nasional.

BAZNAS berkedudukan di ibu kota dan merupakan lembaga pemerintah nonstruktural yang bersifat mandiri dan bertanggung jawab kepada Presiden melalui Menteri. Dalam melaksanakan tugasnya BAZNAS menyelenggarakan 4 (empat) fungsi. Pertama, perencanaan pengumpulan, pendistribusian, dan pendayagunaan zakat. Kedua, pelaksanaan pengumpulan, pendistribusian, dan pendayagunaan zakat. Ketiga, pengendalian pengumpulan, pendistribusian, dan pendayagunaan zakat. Keempat, pelaporan dan pertanggungjawaban pelaksanaan pengelolaan zakat.

Selama 17 tahun menjalankan amanah sebagai badan zakat nasional. Berbagai penghargaan yang telah diraih bagi BAZNAS, antara lain: BAZNAS berhasil memperoleh sertifikat ISO, mendapatkan penghargaan The Best Quality Management dari Karim Business Consulting, predikat Laporan Keuangan Terbaik untuk lembaga non departemen versi Departemen Keuangan RI tahun 2008, meraih "The Best Innovation Programme" dan "The Best in Transparency Management" pada IMZ Award 2011, Global Islamic Finance Award (GIFA) Award, 2018, Anugerah Syariah Republika Award 2018, 2018 dan Global Good Governance Award 2019.

\section{Perkembangan Pengumpulan dan Penyaluran BAZNAS}

Dari aspek pengumpulan, jenis dana yang dikumpukan terdiri dari dana zakat, indak/sedekah serta dana sosial keagamaan lainnya (ZIS dan DSKL). Pengumpulan ZIS dan DSKL pertama kali dilakukan pada tahun 2001 dengan jumlah Rp192.916.825,09. Pada tahun ke delapan belas, BAZNAS berhasil melakukan pengumpulan ZIS dan DSKL sebesar Rp202.077.188.149,00. Bila dihitung secara keseluruhan dari tahun pertama hingga tahun ke delapan belas, maka rata-rata jumlah pengumpulan ZIS dan DSKL per tahun mencapai Rp51.813.797.319,57. Selanjutnya, jumlah ZIS dan DSKL yang telah dikumpulkan selama delapan belas tahun mencapai Rp932.648.351.752,19. Secara rinci, jumlah pengumpulan dari tahun pertama hingga tahun ke tujuh belas dapat dilihat pada tabel di bawah ini.

Tabel 1. Perkembangan Pengumpulan ZIS dan DSKL BAZNAS Periode Tahun 2001-2018

\begin{tabular}{rrr}
\hline No & Tahun & Pengumpulan $(\mathrm{Rp})$ \\
\hline 1 & Tahun 2001 & $192.916 .825,09$ \\
\hline 2 & Tahun 2002 & $728.096 .097,46$ \\
\hline 3 & Tahun 2003 & $2.260 .758 .154,00$ \\
\hline
\end{tabular}


Efri Syamsul Bahri, \& Sabik Khumaini

\begin{tabular}{rrr}
\hline 4 & Tahun 2004 & $3.124 .474 .105,64$ \\
\hline 5 & Tahun 2005 & $31.164 .839 .539,00$ \\
\hline 6 & Tahun 2006 & $16.724 .491 .935,00$ \\
\hline 7 & Tahun 2007 & $10.335 .742 .653,00$ \\
\hline 8 & Tahun 2008 & $17.467 .803 .197,00$ \\
\hline 9 & Tahun 2009 & $24.119 .593 .139,00$ \\
\hline 10 & Tahun 2010 & $26.464 .019 .958,00$ \\
\hline 11 & Tahun 2011 & $39.965 .459 .071,00$ \\
\hline 12 & Tahun 2012 & $50.313 .748 .002,00$ \\
\hline 13 & Tahun 2013 & $59.238304 .066,00$ \\
\hline 14 & Tahun 2014 & $82.293 .545 .780,00$ \\
\hline 15 & Tahun 2015 & $94.333 .127 .895,00$ \\
\hline 16 & Tahun 2016 & $111.684 .020 .431,00$ \\
\hline 17 & Tahun 2017 & $160.160 .222 .755,00$ \\
\hline 18 & Tahun 2018 & $202.077 .188 .149,00$ \\
\hline & Jumlah & $932.648 .351 .752,19$ \\
\hline & Nilai Rata-rata & $51.813 .797 .319,57$ \\
\hline & Nilai Terendah & $192.916 .825,09$ \\
\hline & Nilai Tertinggi & $202.077 .188 .149,00$ \\
\hline Sur. Laporan Kenangan BAZNAS(10lah)
\end{tabular}

Sumber: Laporan Keuangan BAZNAS (diolah)

Dari aspek penyaluran, jumlah penyaluran ZIS dan DSKL selama 18 tahun yaitu: dari tahun 2001 s.d. tahun 2018 sebesar Rp836.512.139.145,00. Rata-rata jumlah Penyaluran per tahun adalah sebesar Rp46.472.896.619,17. Penyaluran terendah pada tahun 2001 sebesar Rp0 atau belum ada yang disalurkan karena pada kondisi awal-awal berdirinya BAZNAS. Penyaluran tertinggi pada tahun 2018 sebesar Rp234.934.754.552,00. Kenaikan yang signifikan terjadi tahun 2005 sebesar Rp15.542.697.991,00 pasca terjadinya Tsunami di Aceh.

Tabel 2. Perkembangan Penyaluran ZIS dan DSKL BAZNAS Periode Tahun 2001-2018

\begin{tabular}{rrr}
\hline No & Tahun & Penyaluran $(R p)$ \\
\hline 1 & Tahun 2001 & 0,00 \\
\hline 2 & Tahun 2002 & $315.277 .246,00$ \\
\hline 3 & Tahun 2003 & $887.769 .327,00$ \\
\hline 4 & Tahun 2004 & $2.058 .918 .822,00$ \\
\hline 5 & Tahun 2005 & $15.542 .697 .991,00$ \\
\hline 6 & Tahun 2006 & $16.775 .858 .503,00$
\end{tabular}




\begin{tabular}{rrr}
\hline 7 & Tahun 2007 & $12.902 .396 .201,00$ \\
\hline 8 & Tahun 2008 & $10.067 .248 .132,00$ \\
\hline 9 & Tahun 2009 & $19.277 .849 .561,00$ \\
\hline 10 & Tahun 2010 & $29.041 .427 .210,00$ \\
\hline 11 & Tahun 2011 & $42.868 .886 .454,00$ \\
\hline 12 & Tahun 2012 & $45.316 .631 .566,00$ \\
\hline 13 & Tahun 2013 & $50.497 .883 .910,00$ \\
\hline 14 & Tahun 2014 & $69.403 .749 .977,00$ \\
\hline 15 & Tahun 2015 & $74.503 .756 .680,00$ \\
\hline 16 & Tahun 2016 & $80.199 .285 .249,00$ \\
\hline 17 & Tahun 2017 & $131.917 .747 .764,00$ \\
\hline 18 & Tahun 2018 & $234.934 .754 .552,00$ \\
\hline & Jumlah & $836.512 .139 .145,00$ \\
\hline & Nilai Rata-rata & $46.472 .896 .619,17$ \\
\hline Nilai Terendah & 0,00 \\
\hline & Nilai Tertinggi & $234.934 .754 .552,00$ \\
\hline Sumber: Laporan Keuangan BAZNAS
\end{tabular}

Sumber: Laporan Keuangan BAZNAS (diolah)

Perkembangan jumlah penyaluran dari tahun ke tahun terus mengalami peningkatan, sebagaimana diuraikan pada grafik di bawah ini. Peningkatan penyaluran zakat tentu akan meningkatkan manfaat zakat kepada mustahik. Peningkatan jumlah penyaluran BAZNAS juga seiring dengan adanya inovasi program yang mencakup 5 (lima) bidang program, yaitu: pendidikan, ekonomi, kesehatan, kemanusiaan serta dakwah dan advokasi.

Grafik 1. Perkembangan Penyaluran ZIS dan DSKL BAZNAS Periode Tahun 2001-2018

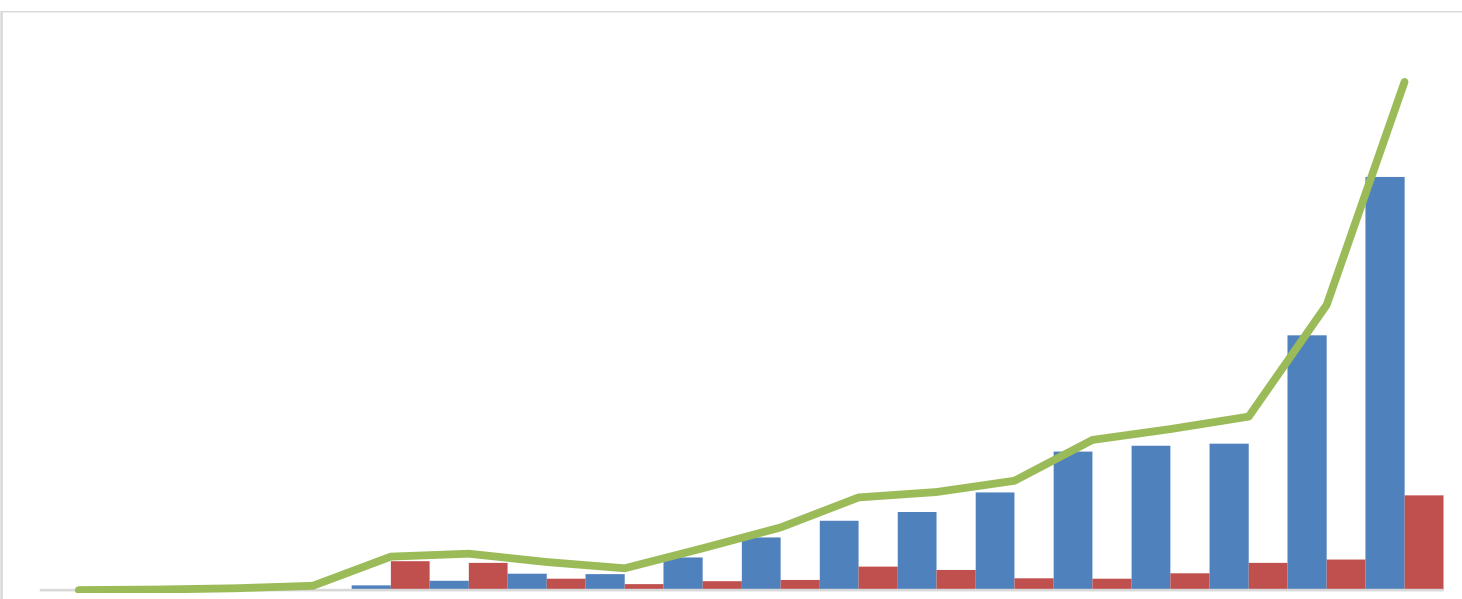

200120022003200420052006200720082009201020112012201320142015201620172018

Sumber: Laporan Keuangan BAZNAS, diolah 


\section{Efektivitas Penyaluran BAZNAS}

Efektivitas penyaluran menggambarkan pencapaian penyaluran zakat periode tertentu, baik jangka pendek, menengah atau jangka panjang. Untuk mengoptimalkan penyaluran zakat tersebut, maka amil zakat mesti melakukan pengelolaan dengan baik dengan menyusun perencanaan penyaluran, strategi pelaksanaan, pelaksanaan pengendalian serta pelaporan yang baik. Dengan demikian, mustahik merasakan manfaat dan keberkahan zakat. Semakin efektiv penyaluran, maka semakin besar manfaat zakat yang dirasakan oleh mustahik.

Di dalam Zakat Core Principle (BAZNAS, 2016, hal. 26) dijelaskan bahwa untuk menilai kinerja penyaluran zakat dapat dilihat dari rasio pendistribusian terhadap pengumpulan zakat. Semakin tinggi rasio penyaluran terhadap pengumpulan zakat, maka semakin efektif pengelolaan zakat. Tingkat efektifitas yang tinggi juga menggambarkan bahwa zakat dikelola dan disalurkan kepada mustahik dengan baik. Semakin cepat zakat disalurkan kepada mustahik akan semakin baik. Oelh karena itu, cara dan batas waktu penyaluran perlu menjadi perhatian bagi amil zakat.

Pengukuran tingkat efektivitas penyaluran zakat BAZNAS di dalam penelitian ini dilakukan dengan menggunakan metode Zakat Core Principles (ZCP), yaitu: ratio efektivitas penyerapan dana zakatnya atau disebut Allocation to Collection Ratio (ACR). Rasio ACR bertujuan untuk mengukur kemampuan sebuah lembaga zakat dalam menyalurkan dana zakatnya dengan cara membagi total dana penyaluran dengan total dana penghimpunan.

Sesuai dengan metode ACR, tingkat efektivitas dibagi kedalam kategori sebagai berikut: 1. Highly Effective (jika ACR $\geq 90$ persen) 2. Effective (jika ACR mencapai 7089 persen) 3. Fairly Effective (jika ACR mencapai 50- 69 persen) 4. Below Expectation (jika ACR mencapai 20- 49 persen) 5. Ineffective (jika ACR < 20 persen).

Berdasarkan ZCP, maka tingkat efektivitas penyaluran selama 18 tahun beroperasi sebesar $90 \%$ atau termasuk dalam kategori High Effective, dimana jumlah pengumpulan selama periode 2001 sampai dengan 2018 sebesar Rp932.648.351.752,19. Sedangkan jumlah penyaluran selama periode 2001 sampai dengan 2018 sebesa Rp836.512.139.145,00. Berdasarkan ZCP tingkat efektivitas penyaluran selama 18 tahun beroperasi sebesar 90\% (sembilan puluh persen). Hal ini menunjukkan bahwa tingkat efektivitas penyaluran ZIS dan DSKL BAZNAS selama 18 tahun berada pada kategori Sangat Efektif dimana Alocation to Collection Ratio (ACR) mencapai $\geq 90$ persen.

\section{KESIMPULAN}

Hasil penelitian ini menunjukkan bahwa jumlah pengumpulan zakat termasuk infak/sedekah dan dana sosial keagamaan lainnya (ZIS dan DSKL) selama 18 tahun dari tahun 2001 sampai dengan tahun 2018 sebesar Rp932.648.351.752,19. Selanjutnya, jumlah penyaluran zakat juga termasuk infak/sedekah dan dana sosial keagamaan lainnya (ZIS dan DSKL) pada periode selama 18 tahun dari tahun 2001 sampai dengan tahun 2018 sebesar Rp836.512.139.145,00. Penyaluran zakat BAZNAS mencakup 8 asnaf yaitu: Fakir, Miskin, Amil, Muallaf, Riqob, Ghorimin, Ibnu sabil dan Fii sabilillah, yang mencakup 5 (lima) bidang yaitu: pendidikan, ekonomi, kesehatan, kemanusiaan serta dakwah dan advokasi. Berdasarkan ZCP tingkat efektivitas penyaluran selama 18 tahun beroperasi sebesar $90 \%$ atau termasuk dalam kategori High Effective. Artinya, zakat 
disalurkan kepada mustahik dalam waktu yang cepat. Saran dari penelitian ini adalah agar BAZNAS dapat mempertahankan bahkan meningkatkan efektivitas penyaluran zakat dengan tingkat efektivitas di atas $80 \%$.

\section{REFERENSI}

Atabik, A. (2016). Peranan Zakat Dalam Pengentasan Kemiskinan. Jurnal Zakat dan Wakaf, 340.

Bahri, E. S. (2018, Desember 1). Geliat Zakat Community Development di Desa Jirak. https://sharianews.com/.

Bahri, S. d. (2018). Komparasi Standar Akuntansi Organisasi Nirlaba dan Standar Akuntansi Organisasi Pengelola Zakat. Ziswaf : Jurnal Zakat dan Wakaf, 5(2). doi:10.21043/ziswaf.v5i2.4336

BAZNAS. (2016). Dokumen Rencana Strategis Zakat Nasional 2016-2020. BAZNAS.

BAZNAS, P. (2018). Outlook Zakat Indonesia 2018. Jakarta: Puskas Baznas.

Chaniago, S. A. (2015). Pemberdayaan Zakat Dalam Mengentaskan Kemiskinan. Jurnal Hukum Islam, Volume 13, Nomor 1, Juni 2015. Diambil kembali dari ejournal.stain-pekalongan.ac.id/index.php/jhi

Damanhur. (2017). The Model of Productive Zakat Distribution In Increasing The Society Welfare In Aceh Province. Journal Of Humanities And Social Science (IOSR-JHSS), 22(11), 77-82. doi:10.9790/0837-2211067782

Deni Lubis, D. B. (2018). Mengukur Kinerja Pengelolaan Zakat di Badan Amil Zakat Nasional. Jurnal Ekonomi dan Bisnis Islam.

Dhaif, S. (2011). Al-Mu'jam Al-Wasith. Mesir: Maktabah Shurouq ad-Dauliyyah (Mesir), 2011.

Efri Syamsul Bahri, M. M. (2019). Maqasid Al-Shariah in Micro-entrepreneurs Development : an Overview. International Conference of Zakat 2019 Proceedings (hal. 258-267). Jakarta: Puskas BAZNAS.

Firmansyah. (2013). Zakat Sebagai Instrumen Pengentasan Kemiskinan dan Kesenjangan Pendapatan. Jurnal Ekonomi dan Pembangunan Vol, Vol 21, No. 2, 179-190.

Harahap, K. (2016). Kebijakan Pengelolaan Keuangan Publik pada Masa Kekhalifahan Umar Bin Abdul Aziz. KJurnal IPTEKS Terapan Research of Applied Science and Education V8.i2 (59-66), Kopertis Wilayah X, ISSN: 1979-9292, hal 62.

Imron Mawardi, T. W. (2018). The Moving Out of Poverty of Mustahiq Productive Zakat in Indonesia. Advances in Social Science, Education and Humanities Research (ASSEHR), 98, 132-137.

KBBI. (t.thn.). Kamus Besar Bahasa Indonesia. Diambil kembali dari https://kbbi.web.id/salur

Khalifah Muhamad Ali, N. N. (2016). Perbandingan Zakat Produktif dan Zakat Konsumtif dalam Meningkatkan Kesejahteraan Mustahik The Comparative 
Study Between Productive and Consumptive Based Zakat. Jurnal Al-Muzara'ah, 19-32.

Kuntjojo. (2009). Metodologi Penelitian. Kediri.

Qardhawi, Y. A. (2016). Hukum Zakat. Lentera Nusa.

Reni Oktaviani, E. S. (2018). Zakat Produktif Sebagai Modal Kerja Usaha Mikro. Perisai, 2(2), 118. doi:10.21070/perisai.v2i2.1686

Rifa'i, B. (2013). Efektivitas Pemberdayaan Usaha Mikro Kecil dan Menengah (UMKM) Krupuk Ikan dalam Program Pengembangan Labsite Pemberdayaan Masyarakat Desa Kedung Rejo Kecamatan Jabon Kabupaten Sidoarjo. Kebijakan dan Manajemen Publik, 1(1), 130-136.

Sabik Khumaini, A. A. (2018). Pemberdayaan Dana Zakat Produktif Terhadap Kesehateraan Umat. Al-Urban, 155-164.

Sartika, M. (2008). Pengaruh Pendayagunaan Zakat Produktif terhadap Pemberdayaan Mustahiq pada LAZ Yayasan Solo Peduli Surakarta. Jurnal Ekonomi Islam La Riba Vol. II, No. 1, Juli 2008.

Setiawan, A. (2017). Rancangan Model Pemberdayaan Pelaku UKM Dalam Upaya Penanggulangan Kemiskinan Dengan Berbasis Zakat Produktif (Studi Kasus Implementasi Program Jatim Makmur Dari Badan Amil Zakat Nasional Provinsi Jawa Timur di Kelurahan Embong Kaliasin Surabaya). Wacana, Jurnal Sosial dan Humaniora, 247-258. doi:10.21776/ub.wacana.2015.018.04.5

Widiastuti, T. (2015). Model Pendayagunaan Zakat Produktif oleh Lembaga Zakat dalam Meningkatkan Pendapatan $\quad$ Mustahiq. Jebis, doi:10.20473/JEBIS.V1I12015.\%P 